\title{
Colonial architecture and urbanism in Africa. Intertwined and contested histories
}

\section{Carlos Nunes Silva}

To cite this article: Carlos Nunes Silva (2013) Colonial architecture and urbanism in Africa. Intertwined and contested histories, Planning Perspectives, 28:1, 156-159, DOI: 10.1080/02665433.2013.736209

To link to this article: https://doi.org/10.1080/02665433.2013.736209

曲 Published online: 08 Nov 2012.

Submit your article to this journal $\widetilde{ }$

III Article views: 355 


\section{Bibliography}

Bonillo, Jean-Lucien, La Reconstruction à Marseille: Architecture et projets urbains, 1940-1960. Marseille: Éditions Imbernon, 2008.

Sandra Parvu
Laboratoire Architecture Anthropologie,
Ecole Nationale Supérieure d'Architecture Paris-La Villette
sandra.parvu@gmail.com
C 2013, Sandra Parvu
http://dx.doi.org/10.1080/02665433.2013.736208

Colonial architecture and urbanism in Africa. Intertwined and contested histories, edited by Fassil Demissie, Farnham, Ashgate, 2012, 438 pp., $£ 70$ (hardcover).

This collection of essays on Colonial Architecture and Urbanism in Africa, edited by Fassil Demissie, is an important contribution to the ongoing debate within the field of colonial studies on the cultural role played by architecture and urbanism in the construction of the European colonial domination in Africa. The book, which originated in a colloquium convened by Fassil Demissie at DePaul University in Chicago in 2005/2006, is organized into three parts (I - Archeology of Colonial Architecture and Urbanism; II - Colonial Disciplinary Institutions; III - Colonial Modernities). It comprises 16 chapters that are written by 19 scholars from different academic backgrounds and an introduction by the Editor with a brief overview of the book.

The book fills part of the gap that still exists in our knowledge about the importance that architecture and urban planning had in the spatial organization and in the social regulation of the local African population in specific local contexts. Similar to other colonial institutions that were introduced and disseminated throughout the continent in the nineteenth and twentieth-centuries (e.g. schools, churches, courts, prisons), the evidence provided by these essays concur with the argument that colonial architecture and colonial urbanism were a complex and multi-dimensional reality and played a significant role in the European cultural project for the colonial domination of Africa. This was particularly the case after the 1884 Berlin Conference. The evidence also shows the constraints faced by colonial urban planning practice, in particular the shortage of qualified planning professionals, the financial burden for the colonizer and the resistance against and subversion of the principles that had emanated from the metropolitan country. These principles were frequently (re-)interpreted by the local African population.

The first part, Archeology of Colonial Architecture and Urbanism, explores in seven chapters different facets of the French, Italian and British colonial architecture and urbanism in Morocco, Libya, Zanzibar, Senegal, South Africa and Zimbabwe. One chapter takes a broader focus on British Colonial Africa as a whole. The research reported in these essays shows how colonial architecture and colonial urbanism were closely related to the architecture and urban planning practiced in the metropolitan countries, where urban planning was a key tool 
within the state apparatus for social control in the rapidly growing industrial cities in the nineteenth-century Europe. Some of these essays provide evidence of an equivalent use of urban planning and architecture in the colonial cities in Africa, for example to control the mobility of the indigenous African population, to promote geographic and residential segregation, to further cultural identity formation and to serve racial dominance. As a specific method of classifying, producing, representing and communicating knowledge about the built environment and the everyday life, colonial architecture and colonial urbanism were key tools in the rationale of racial segregation and European control in Africa.

The French and British experiences are particularly clear in this regard, as shown, for the French case, by Hassan Radoine in Chapter 1 (French Territoriality and Urbanism: General Lyautey and Architect Prost in Morocco, 1912-1925), and by Richard Harris and Susan Parnell, for the British colonial experience, in Chapter 6 (The Turning Point in Urban Policy for British Colonial Africa, 1939-1945). The reciprocity of influence, from the colony to the metropolitan homeland, is also a feature of the colonial process, as highlighted in previous research on urbanism and architecture, and exemplified, among other case-studies reported in the book, by Libya, examined by Vittoria Capresi in Chapter 2 (Architectural Transfer, Italian Colonial Architecture in Libya: 'Libyan Rationalism' and the Concept of 'Mediterraneity', 1926-1942).

The evidence provided in these chapters supports the view that colonial architecture and urbanism in Africa reflected the principles defined and practiced in the respective European metropolitan country, but at the same time tended to incorporate certain local and indigenous forms and aesthetics as part of the strategy to legitimize the European colonial rule. The essays provide ample evidence on how in both British and French colonies architecture incorporated elements of indigenous aesthetics, in particular in the design of public buildings, in order to suppress or diminish local resistance. The essays also explore the different ways African subjects negotiated, contested and reworked the imposition of such specific colonial architecture models. This hybrid and eclectic architecture and urbanism, on one side, and the use of colonial architecture and colonial urbanism as the image of the Empire, is well documented, among other texts, in the chapters of Part I. For example, in Chapter 3 (Imperial Sanctuaries: Arab Urban Enclaves on the East African Coast) Mohamed El Amrousi shows how colonial planners allowed different cities to develop their own system through cultural rituals, as was the case in Zanzibar and in Port Said. In Chapter 4 (The Point of Pointed Architecture: Its Revival in Europe and its Appearance in 'Colonial' Mosques) Cleo Cantone offers new evidence on the complexity of the relationship between colonizer and colonized, which is based on the case of colonial mosques. In Chapter 5 (Whose Colony, and Whose Legacy? Layers of Power and Hybrid Identities in Edendale, Pietermaritzburg, South Africa) Debbie Whelan presents an atypical situation, in which the colonizers were not necessarily of European descent. Thus, she highlights the complexity of the relationship between colonizers and colonized. Chapter 7 ('Aya Mahobo': Migrant Labour and the Cultural Semiotics of Harare (Mbare) African Township, 1930-1970) by Maurice Taonezvi Vambe shows how African migrants negotiated their new identities in ways that reflect, among other aspects, a desire to establish possession of the physical space in Mbare.

This is followed, in the second part of the book (II - Colonial Disciplinary Institutions), by six chapters that explore the links between colonial architecture and colonial urbanism and the development of institutions to regulate the everyday life of Africans. Case studies include penal architecture, school architecture, ecclesiastic architecture and the symbolic buildings used 
as metaphors of colonial hegemony (e.g. Senegal, Congo, Southern and Central Africa, Burundi, Kenya). These chapters reinforce the view already presented in the first part about the influence of the metropolitan model and the relative autonomy of the solutions adopted in the architecture of key public institutions and in the organization of the urban space. This facet of the colonizerscolonized relationship is well illustrated by Dior Konaté in Chapter 8 (Penal Architecture: An Essay on Prison Designs in Colonial Senegal), by Bram Cleys and Bruno De Meulder in Chapter 9 (Imagining a Christian Territory: Changing Spatial Strategies in the Missionary Outposts of Scheut - Kasai, Congo, 1891-1940), by G.A. Bremmer in Chapter 10 (Pro Fide et Patria: Anglicanism and Ecclesiastical Architecture in Southern and Central Africa, 18481903), by Johan Lagae in the following chapter (Montcassin, Montserrat or ... an Alcazar? Architecture, Propaganda and Everyday School Practices in the Collège du Saint-Esprit in Bujumbura - Burundi), by Mark Hinchman in Chapter 12 (The Grid of Saint-Louis du Sénégal), and by Maurice Amutabi in the last chapter of this section (Buildings as Symbols and Metaphors of Colonial Hegemony: Interrogating Colonial Buildings and Architecture in Kenya's Urban Spaces).

The third and last part of the book (III - Colonial Modernities) examines different aspects of the colonial architecture and planning practices and discusses the links between these practices and the principles and practices in the European metropolitan centers. Rhodri Windsor-Liscombe in Chapter 14 (Building Dominion and the Colonial Overseas: The Culture of British Fabrics of Financial Intervention in (South) Africa (at the End of the Empire) explores the cultural role of a financial institution through architecture in the last period of the British Empire. In the following chapter (Das Neue Afrika: Ernst May's 1947 Kampala Plan as Cultural Programme) Kai K. Gutschow examines and discusses the work of the architect and planner Ernst May in Africa. In the last chapter, Cristina Salvador and Cristina Udelsmann Rodrigues offer a study of the Portuguese colonial architecture (Colonial Architecture in Angola: Past Functions and Recent Appropriations), exemplified by old colonial buildings, schools, cinemas and markets, in the cities of Luanda, Benguela and Lobito. They suggest that the location of spaces and buildings with similar functions influenced the evolution of their use and appropriation in the transition to the postcolonial period. The evidence points also to the fact that the preservation of this colonial architecture, in the few cases in which it happened, was only possible through the intervention of public institutions.

In summary, the 16 essays included in this collection are undoubtedly a positive and very important addition to the effort being made in the last years to uncover the multiple ways in which colonial architecture and colonial urbanism contributed to European colonial domination through their specific discourse and practices. They also show how 'governmentality' tools (in the sense Foucault used the concept), perhaps to a greater extent than military tools made the Empire visible to the colonized. However, not all aspects of the European colonial presence are examined in the book. Some are only marginally touched, as the Portuguese colonial architecture and colonial urbanism, explored in the chapter on colonial architecture in Angola or the period of European colonization before the nineteenth century. The latter was a relatively long period during which a variety of architectural solutions and urban planning models were experimented and applied.

For that reason, further research on specific aspects of colonial urbanism will be required to get the full picture of the role architecture and urban planning played in the European colonial project in Africa. This includes in particular a comparison of how different European planning 
cultures (Anglophone, Francophone, Lusophone, etc.) were translated into the respective African colonies, and a re-interpretation of existing evidence through the lens of new scholarship about how knowledge emerges as a specific type of power.

\author{
Carlos Nunes Silva \\ Institute of Geography and Spatial Planning \\ University of Lisbon \\ cs@campus.ul.pt \\ (C) 2013, Carlos Nunes Silva \\ http://dx.doi.org/10.1080/02665433.2013.736209
}

L'invention du Vieux Paris. Naissance d'une conscience patrimoniale dans la capitale, by Ruth Fiori, Wavre, Mardaga, 2012, 327 pp., €39 (paperback), preface by Dominique Poulot

The book by Ruth Fiori stands out in the recent publications on the theme of architectural and urban conservation in Paris. A reworked doctoral thesis (University of Paris I, 2009), the book mostly focuses on the years 1885-1910, the years that saw the emergence of groupements de sauvegarde such as the Société des amis des monuments parisiens created by Charles Normand (1885), the municipal Commission du vieux Paris (1898), and many other local societies for the protection of heritage. These constitute the object of the survey conducted by the author in order to identify the origin of heritage consciousness in the French capital. The volume is therefore not a simple inquiry on the emergence of the concept of vieux Paris, but involves an investigation into a network of associations and their various ways of action.

Two approaches put this book well beyond the history of the preservation of a city's monuments. On the one hand, Ruth Fiori is interested in the relationship between vieux Paris and modern Paris, between the protection of heritage and the development of the contemporary city: the spread of the immeuble de rapport during the last three decades of the nineteenth century is taken as a significant example of this development. On the other hand, the author focuses on the urban scale: this is especially apparent in her examination of the first attempts to protect the urban landscape, which paralleled the first campaigns to save natural landscapes. Ruth Fiori explores a plurality of ways by which urban heritage was historicized: the book proposes an articulated analysis of different cultural projects, such as the birth of the Musée Carnavalet in 1866, the photographic campaigns carried out by Eugène Atget, the Vieux Paris attraction conceived by Albert Robida for the International Exhibition in Paris in 1900. The analysis also takes into account a plurality of editorial undertakings, such as Turpin de Crissé's Souvenirs du vieux Paris, Pernot's Vieux Paris, the Topographie du Vieux Paris, and the monumental Statistique de Paris published by Albert Lenoir.

Far from evoking an epic, the author observes the constant attempt to reconcile conservation of the old town and growth of the new one. Therefore, she proposes the analysis of some exemplary moments, starting with the debates (1870-1884) on the ruins of the Roman amphitheatre and on the ancient urban system of mills such as the moulin de la Charité (1893). 